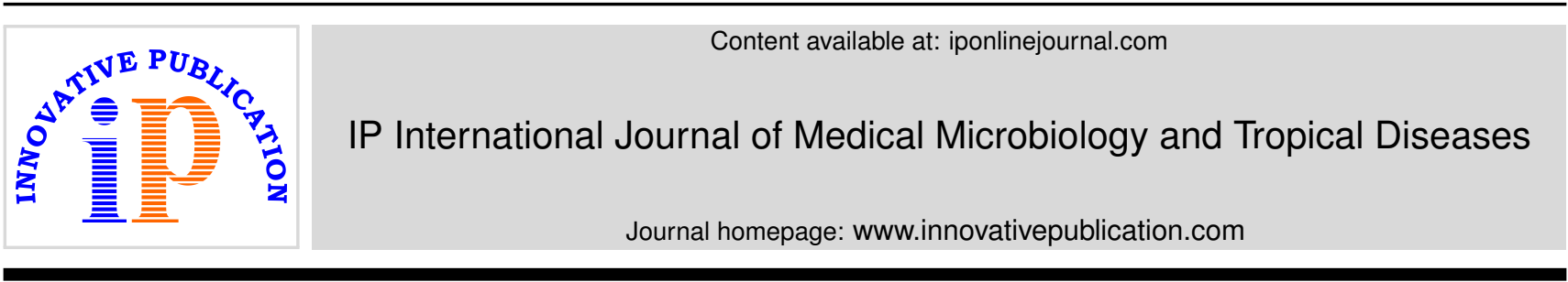

Original Research Article

\title{
Bacteriological profile in microbiology surveillance of operation theatres: A retrospective study at a tertiary care teaching hospital in Rajsamand district, Rajasthan
}

\author{
Shweta Bohra ${ }^{1}$, Ritu Bhatnagar ${ }^{1, *}$ \\ ${ }^{1}$ Dept. of Microbiology, Ananta Institute of Medical Sciences \& Research Centre, Siyol, Rajasthan, India
}

\section{A R T I C L E I N F O}

\section{Article history:}

Received 11-04-2020

Accepted 18-05-2020

Available online 06-07-2020

\section{Keywords:}

Air sampling

OT

Settle plate method

Surveillance

\begin{abstract}
A B S T R A C T
Introduction: Contamination of operation theatres and Intensive care units through air, surface or article vehicle is major cause of surgical site and hospital acquired infections leading to increased morbidity and mortality.

Aims and Objective: The present study was conducted with aim to isolate and identify the nature of microbial contamination through air, surface and equipment of OT in a tertiary care teaching hospital.

Materials and Methods: Six months (August 2019 - January 2020) retrospective analysis of data by random sampling of the six OT's of the hospital was done. Air sampling was done by settle plate method. Surface samples were taken from different sites and equipments from the OT. Bacterial species were isolated and identified by conventional methods.

Results: Total 300 samples were collected and analysed Out of which 116 samples (38.66\%) were positive for bacterial growth. The predominant bacterial species isolated from surface or equipment was Bacillus (48.27\%), followed by Coagulase Negative Staphylococcus (21.55\%), Gram Negative bacilli i.e. Klebsiella (8.62\%) and least commonly isolated bacterial species was Staphylococcus aureus 2(1.72\%). Air quality analysis showed highest bacterial $\mathrm{CFU}$ rate of $75 \mathrm{cfu} / \mathrm{m} 3$ from general surgical operation theatres and Ophthalmology OT recorded least bacterial cfu rate of $20 \mathrm{cfu} / \mathrm{m} 3$. Most common isolated species was Baciilus followed by Coagulase Negative Staphylococcii.

Conclusion: The study revealed that the OT's of our hospital showed a low bacterial contamination rate on surface swabbing and air quality CFU count per mm3 were within permissible limits. The present study emphasizes the need for periodic surveillance of OT's and ICU's and highlight the importance of early detection of bacterial contamination levels and prevention of hospital acquired infections.

(C) 2020 Published by Innovative Publication. This is an open access article under the CC BY-NC license (https://creativecommons.org/licenses/by-nc/4.0/)
\end{abstract}

\section{Introduction}

Hospital premises is in itself home to many kind of infections and have a potential role in transmission of so called Healthcare Associated Infections (HAI), also known as Noscomial or Hospital Aquired Infections. Hospital environmental hygiene plays very critical role in prevention of Hospital Aquired Infections and effective implementation of Hospital Infection Control programmes. HAIs are known to increases the morbidity, mortality and effective cost

\footnotetext{
* Corresponding author.

E-mail address: dr_shwetajoshi@yahoo.in (R. Bhatnagar).
}

of treatment by increase in hospital stay. ${ }^{1}$ Microbial contamination poses major risk factor in occurrence of surgical site infection (SSI). ${ }^{2}$ Invasive procedures done without proper aseptic measures, irrational antibiotic usage and transmission of microbial infection between patients due to inadequate hospital infection control measures leads emergence and spread of microbial resistance in hot zones like OT's and ICU's. ${ }^{3}$

Microbiological surveillance is an important aspect of Infection control Programme, providing data regarding types and counts of microbial flora from various sites of healthcare facilities. ${ }^{4}$ Knowledge of the incidence of 
micro flora in a hospital is important for implementation of planning of adequate cleaning of hospital environment leading to prevention of further infections.

\section{Aims \& Objective}

The present study was conducted to isolate and identify bacteriological profile and to evaluate the level of bacterial contamination found in surveillance of surface, equipment and air samples from various speciality OT's. It also aims at strengthening the Infection control strategy of the hospital towards prevention of HAI.

\section{Materials and Methods}

This retrospective study was conducted at the Department of Microbiology, Ananta Institute of Medical Sciences and Research Centre, Rajsamand Rajasthan over a period of six months from August 2019 - January 2020. The study is approved by Institutional Ethical Committee. The study includes random Air and Surface sampling from Operation Theatres. Samples were taken without prior information to nursing and cleaning staff so that true picture can be brought out.

Sampling procedures used in the study were surface swabbing and settle plate method. ${ }^{5}$ All standard operating procedures were followed while taking samples. Sterile swabs soaked in nutrient broth were used for collecting samples from different sites and equipments (Instrument trolley, Anaesthesia trolley, table top, OT light, Monitor, Suction apparatus, Crash cart, IV infusion pump, door handle) from six OTs of the hospital. ${ }^{6}$

After labelling them properly, samples were transported to microbiology laboratory immediately for further processing. Blood agar and MacConkey agar culture plates were inoculated and incubated at 37 degree centigrade for 24 hours aerobically. Isolated bacterial species were identified by conventional method. ${ }^{7}$ Air sampling was done by settle plate method. Blood agar plates were taken in OT and labelled with sample number, site, time and date. Plates were kept at about 1meter above the ground and 1 meter from the wall at the center of OT and four corners. ${ }^{8}$ Plates were exposed for an hour, at the time when OT's were functional. Exposed plates were sealed in plastic bags and sent to microbiology laboratory. Plates were incubated at 37degree centigrade for 24 hours. Colonies were counted and bacterial isolates were identified by conventional methods. Further, the colony forming unit (cfu) per plate was expressed as $\mathrm{cfu} / \mathrm{m}^{3}$ by Omeliansky formula. ${ }^{9}$

\section{Results}

Total 300 samples were processed, out of which bacterial species were isolated from $116(38.66 \%)$ samples. Rest swab samples were sterile.
The Bacterial cfu/m $\mathrm{m}^{3}$ counts of air from all OTs ranged from $20 \mathrm{cfu} / \mathrm{m}^{3}$ (isolated from Opthalmology OT) to $75 \mathrm{cfu} / \mathrm{m}^{3}$ (isolated from General Surgery OT).

Table 1: Bacterial colony count on air sampling of various OT's.

\begin{tabular}{ll}
\hline Name of OT & Colony count $\left(\mathbf{c f u} / \mathbf{m}^{3}\right)$ \\
General Surgery & $75 \mathrm{cfu} / \mathrm{m}^{3}$ \\
Urology & $65 \mathrm{cfu} / \mathrm{m}^{3}$ \\
Gynaecology \& Obstetrics & $55 \mathrm{cfu} / \mathrm{m}^{3}$ \\
ENT & $25 \mathrm{cfu} / \mathrm{m}^{3}$ \\
Orthopaedics & $23 \mathrm{cfu} / \mathrm{m}^{3}$ \\
Opthalmology & $20 \mathrm{cfu} / \mathrm{m}^{3}$ \\
\hline
\end{tabular}

Table 2: Various Bacterial isolates from different OTs in Air sampling.

\begin{tabular}{ll}
\hline Name of OT & Microbes isolated \\
Orthopaedics & Bacillus, CoNS \\
Urology & CoNS \\
Gynaecology \& Obstetrics & Bacillus, CoNS \\
General Surgery & Bacillus, CoNS, Micrococci \\
ENT & Bacillus, CoNS \\
Opthalmology & Bacillus, CoNS \\
\hline
\end{tabular}

Bacillus species and Coagulase Negative Staphylococci (CoNS) were the most common isolates from different OTs in air sampling.

Table 3: Number of Bacterial isolates obtained from OTs in Surface Sampling.

\begin{tabular}{lll}
\hline Bacterial isolates & Number & \% (n=116) \\
Bacillus & 56 & $48.27 \%$ \\
CoNS & 25 & $21.55 \%$ \\
Klebsiella & 10 & $8.62 \%$ \\
Escherichia coli & 08 & $6.89 \%$ \\
Micrococci & 07 & $6.03 \%$ \\
Acinetobacter species & 05 & $4.31 \%$ \\
Pseudomonas species & 03 & $2.58 \%$ \\
Staphylococcus aureus & 02 & $1.72 \%$ \\
\hline
\end{tabular}

Out of Total Positive Bacterial isolates most common was Bacillus (48.27\%), followed by $\operatorname{CoNS}(21.55 \%)$ and least common Staphylococcus aureus (1.72\%).

\section{Discussion}

Microbial contamination in OT leading to post operative infections can have serious implications for patients and their close contacts. A case of suspected HAIs is aggressively investigated by performing cultures from body sites of target patient, other close patients, health care staff working in wards and ICU's and environment. ${ }^{10}$

Specimens must be selected very carefully to obtain authentic and meaningful results. Hospital acquired infections prolongs patients hospital stay, increases morbidity, increase resistance to antimicrobials, represent a additional 
financial burden for health system and cause unnecessary deaths. 5

Prevention measures that need to be practiced to avoid such critical situations rest not only with the operating personnel but also with the entire infection control team. In this context, monitoring and microbiological surveillance can serve as warning system for change in the type and count of microbial flora. ${ }^{11}$

Hygienic condition of operation theatre is reflected by Microbiological quality of its air. Settle plates are believed to be more sensitive in detecting any deterioration in the microbial contamination of air in the operation theatre and conditions that could compromise the quality of the air in OT. ${ }^{12}$

In the present study, the count ranged between 20 $75 \mathrm{cfu} / \mathrm{m}^{3}$ of air which is well within permissible limits and correlate well with studies from Dipendra et al and Desai et al, ${ }^{5,13}$ where as Anjali et al ${ }^{11}$ have reported a high counts from air sampling. Variability in results in different studies can be attributed to various factors like method of surveillance, time of sampling (random /operational), ventilation of OT, disinfectants and method of sterilization used in infection control program. Highest colony forming unit count per cubic meter of air in our study was observed from General Surgery OT and least with Ophthalmology OT which coincides with study by Dipendra et al. High count seen in General Surgery OT's can be directly related to patient load in General Surgery OT and infective profile of patients in General surgery compared to Ophthalmic OT. ${ }^{5}$

In surface sampling, out of total 116 positive samples (38.66\%), Bacillus species was most common isolate $(48.27 \%)$ which is also considered to be environmental contaminant, followed by $\operatorname{CoNS}(21.55 \%)$ which is a common commensal organism and are also an important cause of SSI, ${ }^{5}$ and shedding of CoNS from skin of Healthcare workers and patients and its easy cross transmission may be the reason for its presence in the study. This coincides with other studies by Pasquarella et al., and Desai et al. ${ }^{12,13}$ In our study least common isolate was Staphylococcus aureus $(1.72 \%)$ which is a potential pathogen and an important cause of skin and soft tissue infection. The instruments and article which were sterilised by autoclave showed no growth and highly touched surfaces like door handles, IV stand and OT lights also showed no growth of bacteria.

\section{Conclusion}

Our study shows that the microbiological quality of air and surfaces in OT of our hospital is satisfactory. This data can be used to set regional standards for level of acceptable microbial population and for suggesting guidelines to decrease the microbial population rates in indoor air.

The high prevalence of infective sources in hospital operation theatre environment is alarming and there is a need for strengthening of surveillance and proper implementation of infection control protocol which should be adopted at all levels of health care. Therefore, more extensive studies are required in the field for monitoring, surveillance methods and comparison of compliance between healthcare facilities, along with infection control measures which will be very useful in controlling HAIs.

\section{Source of Funding}

None.

\section{Conflicts of Interest}

None.

\section{References}

1. Ananthanarayan, Panicker's. Textbook of Microbiology; 2017. p. 648.

2. Fleischer M, Bober-Gheek B, Bortkiewicz O, Rusiecka-Ziólkowskaa J. Microbiological Control of Airborne Contamination in Hospitals. Indoor Build Environ. 2006;15(1):53-6.

3. Hanberger H, Arman D, Gill H, Jindrak V, Kalenic S, Kurcz A. Surveillance of Microbial Resistance in European Intensive Care Units: A First Report From the Care-ICU Programme for Improved Infection Control. Intensive Care Med. 2009;35(1):91-100.

4. Sandle T. Environmental monitoring risk assessment. J GXP Compliance. 2006;10:54-73.

5. Najotra D, Malhotra A, Slathia P, Raina S, Dhar A. Microbiological surveillance of operation theatres: Five year retrospective analysis from a Tertiary Care Hospital in North India. Int J App Basic Med Res . 2017;7(3):165-8.

6. Deepa S, Abishek MU, Venkatesha D. The air as harbinger of infections in critical care units. Med Sci. 2014;8:8-13.

7. Collee JG, Miles RS, Watt B. Tests for the identification of bacteria. Edinburg: Churchill Livingstone; 1996. p. 131-50.

8. Pasquarella C, Pitzurra O, Savino A. The index of microbial air contamination. J Hosp Infect. 2000;46(4):241-56.

9. Hameed A, Habeeballah T. Air Microbial Contamination at the Holy Mosque, Makkah, Saudi Arabia. Curr World Environ. 2013;8(2).

10. World Health Organization, Regional Office for South-East Asia. New Delhi. Guidelines on Pre vention and Control of Hospital Associated Infections; 2002.

11. Anjali K, Anamika V, Mrithunjay K, Dalal AS, Kumar A. Environmental microbiological surveillance of operation theatres in a tertiary care hospital. Int J Curr Res. 2015;7:13977-80.

12. Pasquarella C, Masia MD, Nnanga N, Sansebastiano GE, Savino A, Signorelli C, et al. Microbial air monitoring in operating theatre: Active and passive samplings. Ann Ig. 2004;16:375-86.

13. Desai SN, Kikani KM, Mehta SJ, Microbilogical. Surveillance of Operation Theaters \& Intensive Care Units of Teaching Hospital in Surendranagar, Gujarat. . Gujrat Med J. 2012;67.

\section{Author biography}

Shweta Bohra Assistant Professor

Ritu Bhatnagar Associate Professor

Cite this article: Bohra S, Bhatnagar R. Bacteriological profile in microbiology surveillance of operation theatres: A retrospective study at a tertiary care teaching hospital in Rajsamand district, Rajasthan. IP Int J Med Microbiol Trop Dis 2020;6(2):120-122. 